\title{
Ultrasonic fields and inspection of composites
}

\section{Pola ultradwiękowe i badania kompozytów}

\section{Abstract}

Composites are widely used in aerospace, shipbuilding, automobile industry and other fields. Reliability and effectiveness of composites whose primary structural components are fiber-reinforced material need a significant demand for nondestructive testing.

Mathematical modeling has evolved as an important tool to providing an aided analysis and optimize experimental setups [1]. Modeling will help to reveal the quantitative features relationship in ultrasonic physical phenomena and to accelerate the development of new NDT techniques. Gaussian beam superposition technique has been developed for homogeneous anisotropic materials and extended to simulate in inhomogeneous structures [2]. Modeling the transducer generated sound beam in composites is very difficult, especially when the geometry structure and the material component are complex. However, methods based on the paraxial approximations that model the transducer wave field with a superposition of Gaussian beams are computationally efficient and well behaved[3]. In this paper, the multi-Gaussian beam model for calculating ultrasonic acoustic field in anisotropic material is introduced and developed to calculate the propagation and penetration of Gaussian beams in composite materials. It is presented that numerical simulations and experimental results of transmitted ultrasonic field for composites with different thickness are effective. Accuracy of the proposed model is verified by comparing model-based predictions with experimental results.

Automated ultrasonic scanning technology by means of immersion tank and squirter has been extensively applied in composite quality inspection [4]. But the reliability and repeatability of inspection results are strongly depend on the understanding of ultrasonic propagation model in composites [5].
\end{abstract}

\section{Streszczenie}

W pracy przedstawiono wyniki symulacji komputerowej i wyniki pomiarów rozkładu ciśnienia akustycznego fal przechodzących przez płyty kompozytowe o różnych grubościach. Symulacje wykonano dla głowicy ogniskującej pracującej w zanurzeniu. Wpływ kompozytu na kształt wiązki przejawia się głównie w skróceniu długości ogniskowej. W badaniach eksperymentalnych zastosowano głowic o częstotliwości $1 \mathrm{MHz}$ pracujące w zanurzeniu, a badaniu podlegały rozkłady pola akustycznego po przejściu fal przez zbrojone włóknem węglowym próbki kompozytowe o grubościach od 10 do $25 \mathrm{~mm}$.

W drugiej części przedstawione są wyniki badania zakrzywionych próbek kompozytowych zawierających wady sztuczne. Badania wykonano metodą przepuszczania głowicami ze sprzężeniem strumieniem wody. Głowice prowadzone były przez dwa współpracujące roboty. 


\section{Theory}

Multi-Gaussian beam model is used to simulate a sound field of immersion transducer radiating into an anisotropic solid. Most transducer beam models that use a superposition of Gaussian beams rely on works of Wen and Breazeale [6], who showed that the wave field of a circular piston transducer radiating into a fluid could be accurately synthesized by as many as 10 to 15 Gaussians.

\section{Ultrasonic field model}

Using MGB technique, sound pressure distribution of piston transducer in water is:

$p\left(x, y, z_{1}\right)=\sum_{n=1}^{15} \frac{\rho c v_{0} A_{n}}{1+\left(i B_{n} z_{1} / x_{r}\right)} \exp \left(i k_{1} z_{1}\right) \exp \left(-\frac{B_{n}\left(x^{2}+y^{2}\right) / a^{2}}{1+\left(i B_{n} z_{1} / x_{r}\right)}\right)$

where: $A_{n}, B_{n}$ are complex-valued expansion coefficients that need to be determined to match the velocity field on the face of the transducer; $a$ is radius of the transducer; $k=2 \pi / \lambda$ is the wave number; $x_{r}=k a^{2} / 2$ is the Rayleigh distance.

\section{Gaussian Beams in Anisotropic Media}

In an anisotropic medium, we can write down the wave field from a piston transducer, where:

$$
\begin{aligned}
\frac{\mathbf{v}_{M+1}^{\gamma_{M+1}}(\mathbf{x}, \omega)}{\rho_{1} c_{1} v_{0}}= & \sum_{n=1}^{10} A_{n} \frac{\sqrt{\operatorname{det}\left[\mathbf{M}_{M+1}^{Y_{M+1}}\left(s_{M+1}\right)\right]_{n}}}{\sqrt{\operatorname{det}\left[\mathbf{M}_{M+1}^{\gamma_{M+1}}(0)\right]_{n}}} \mathbf{d}_{M+1}^{\gamma_{M+1}} \prod_{m=1}^{M} T_{m ; m+1}^{\gamma_{M+1} z_{M}} \frac{\left.\sqrt{\operatorname{det}\left[\mathbf{M}_{m}^{\gamma_{m}(}\left(s_{m}\right)\right.}\right]_{n}}{\sqrt{\operatorname{det}\left[\mathbf{M}_{m}^{\gamma_{m}}(0)\right]_{n}}} \\
& \times \exp \left[i \omega\left(\sum_{m=1}^{M+1} \frac{s_{m}}{c_{m}^{\gamma_{m}}}+\frac{1}{2} y^{T}\left[\mathbf{M}_{M+1}^{M_{M+1}}\left(s_{M+1}\right)\right]_{n} y\right)\right]
\end{aligned}
$$

Where, $T_{m ; m+1}^{\gamma_{M+1} ; \gamma_{M}}$ is the transmission coefficient at the interface of layer $m$ and $m+1, c_{m}^{\gamma_{m}}$ is the speed of wave $\gamma$ in layer $m(m=1,2, \ldots, M), s_{m}$ is the wave propagating distance in layer $m$.

a)

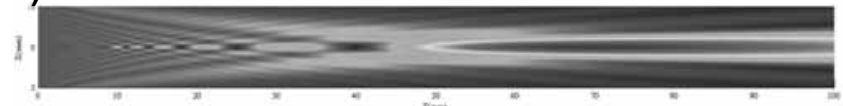

b)

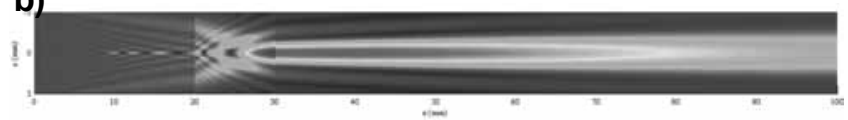

c)

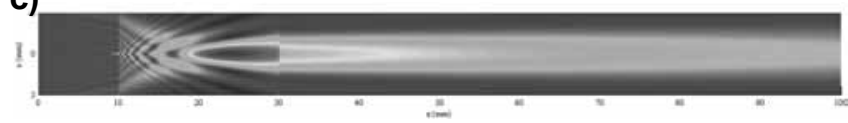

d)

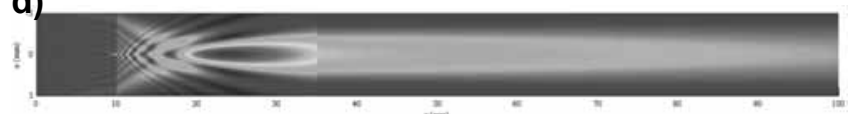

Fig. 1. Ultrasonic field simulation ( $X-Z$ plane): a) ultrasonic field simulation in water, $b$ ) transmitted ultrasonic field behind $10 \mathrm{~mm}$ carbon fiber composite plate, c) transmitted ultrasonic field behind 20 $\mathrm{mm}$ carbon fiber composite plate, d) transmitted ultrasonic field behind $25 \mathrm{~mm}$ carbon fiber composite plate

Rys. 1. Wyniki symulacji pola ultradźwiękowego (płaszczyzna X-Z)
We used a focusing probe whose center frequency is $5 \mathrm{MHz}$, crystal diameter is $12.7 \mathrm{~mm}$ and focal distance is $76.2 \mathrm{~mm}$ in following experiments. Fig. 1 shows the probe's ultrasonic field in water and in the composite plate. It can be seen clearly that the focal distance in composite material is shortening, mainly because that the speed of ultrasonic wave in the composite plate is much bigger than in the water.

\section{Experimental results and discussion}

Fig. 2 shows that the focal distance behind composite plate is shorter than in water. It is because of sound velocity in metal and composite plate is faster than in water. This is consistent with the previous simulation in Fig. 1.

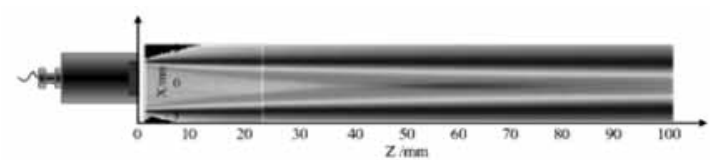

(a) $\mathrm{X}-\mathrm{Z}$ plane ultrasonic field measurement results

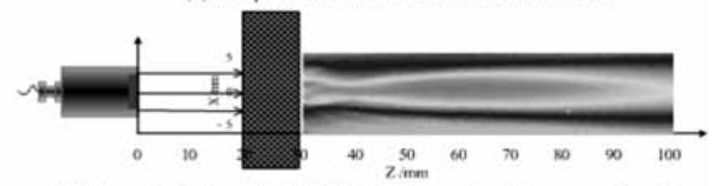

(b) Transmitted ultrasonic field behind $10 \mathrm{~mm}$ carbon fiber composite plate

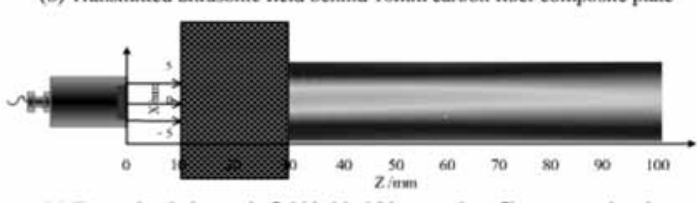

(c) Transmitted ultrasonic field behind $20 \mathrm{~mm}$ carbon fiber composite plate

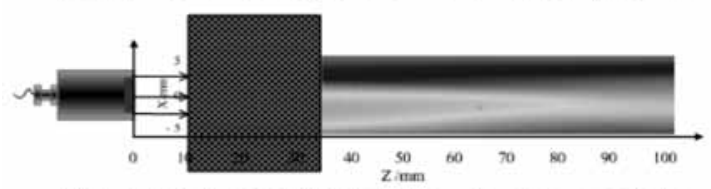

(d) Transmitted ultrasonic field behind $25 \mathrm{~mm}$ carbon fiber composite plate

Fig. 2. X-Z plane transmitted ultrasonic field measurements

Rys. 2. Wyniki pomiarów pola ultradźwiękowego w płaszczyźnie X-Z

\section{Inspection of part with curvatures}

\section{Curved surface trajectory}

In order to ensure more ultrasonic signals transmitted through composites, the transducer should automatically move along the curved surface (as shown in Fig. 5). Therefore, surface following can be described as a scanner's ability to do a controlled displacement of one or multiple axes, with the objective to move around a curved, round, or inclined surface [7]. Performing an automatic inspection must be based on the knowledge of the composites geometry. This can be achieved using different techniques ranging from manual teaching of the surface coordinates by using ultrasonic signals, 
optical or mechanical apparatus, or through the use of the workpiece design drawings. Once the surface coordinates and orientation are known, the motion control technology may calculate a scanning path in which the ultrasonic transducer can move along.

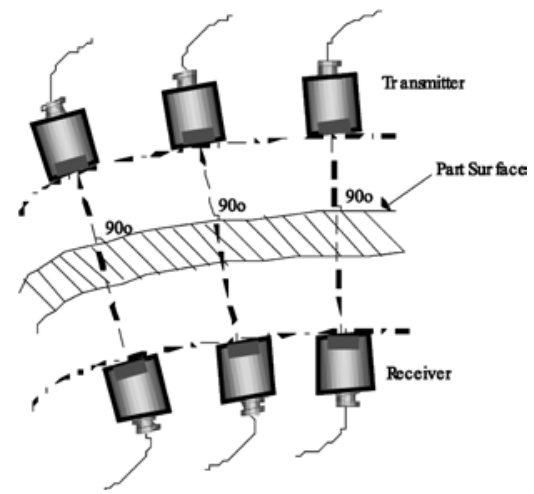

Fig. 3. Curved surface trajectory

Rys. 3. Trajektoria głowic wzdłuż zakrzywionej powierzchnii

\section{Experimental results}

Ultrasonic inspection was performed on an area of curved glass fiber composite part (500 mm $\times 500 \mathrm{~mm} \times 5$ $\mathrm{mm}$ ) containing artificial defects. This sample was inspected using two $1 \mathrm{MHz}$ focused transducers ( $\mathrm{F}=1.5$ ") with a diameter of 0.5 ".

Fig. 4 displays the twin-robot ultrasonic testing system. An automatic inspection was performed with stable water path and proper probe orientation. C-Scan images of curved glass fiber composites containing artificial defects were obtained. The C-Scan results (Fig. 5) show a mapping of the structure and internal artificial defects.
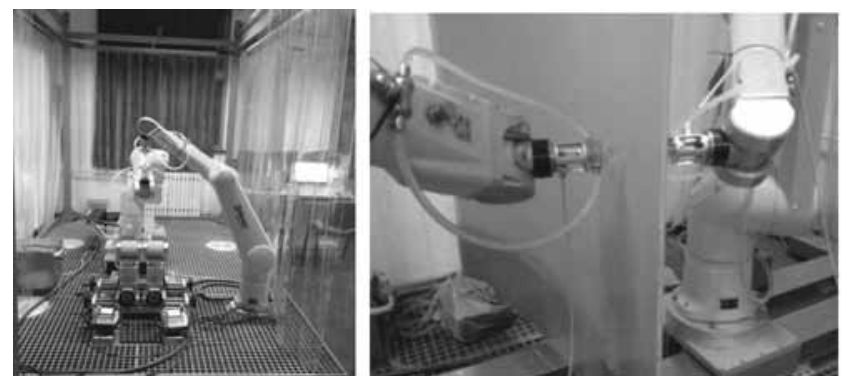

Fig. 4. Twin-robot ultrasonic testing system

Rys. 4. Układ dwóch robotów do automatycznych badań ultradźwiękowych

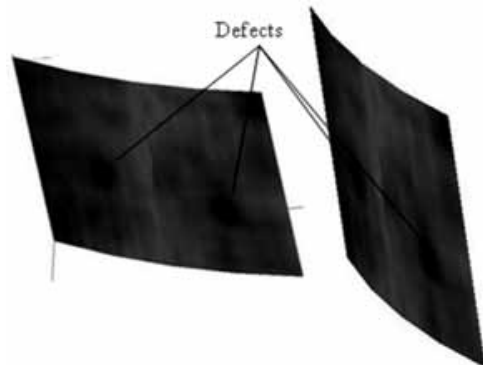

Fig. 5. C-Scan images of curved composites

Rys. 5. Wyniki badania zakrzywionych kompozytów w postaci C-skanów

\section{Conclusions}

A MGB model described the wave field in composites has been given. By measuring transmitted ultrasonic filed, focal distance has been calculated. In order to ensure more ultrasonic signals transmitted through composites, the transducer should automatically move along the curved surface. A twin-robot automatic testing system is employed to accomplish automatic inspection of composites with curvatures.

\section{Literatura}

[1] M. Spies. 2000. "Modeling of Transducer Fields in Inhomogeneous Anisotropic Materials Using Gaussian Beam Superposition." NDT\&E International. 33(3), pp. 155-162.

[2] L. W. Schmerr Jr., A. Sedov. 2003. "A Modular Multi-Gaussian Beam Model for Isotropic and Anisotropic Media". In Review of Progress in QNDE, 22, NY, pp. 828-835.

[3] R. Huang, L. W. Schmerr, A. Sedov. 2007. "Multi-Gaussian Beam Modeling for Multi-layered Anisotropic Media, I: Modeling Foundations. "Research in Nondestructive Evaluation. 18(4), pp. 193-220.

[4] T. D Orazio, M. Leo, A. Distante, C. Guaragnella, V. Pianese, G. Cavaccini. 2008. "Automatic ultrasonic inspection for internal defect detection in composite materials." NDT \& E International, vol. 41, pp. 145-154.
[5] K. Yuan, Z. Han, B. Wang. 2009. "Water-Squirting Ultrasonic C-Scan Testing System for Composite Materials." Aeronautical manufacturing technology, vol. 15, pp. 101-103.

[6] J. J. Wen, M. A. Breazeale. 1988. "A diffraction beam field expressed as the superposition of Gaussian beams." Journal of the Acoustical Society of America. 83(5), pp. 1752-1756.

[7] Ma H W, Zhang X H, Wei J. 2002. "Research on an ultrasonic NDT system for complex surface parts." Journal of Materials Processing Technology, vol. 129, no. 3, pp. 667-670.

\section{Acknowledgements}

The authors would like to acknowledge the Key National Science \& Technology Projects of China (2011ZX04014-081) and Program of International S\&T Cooperation (2012DFA70260). 